\title{
Ortaçağ’da Ulemânın İktidara Karşı Kullandığı Dil/Üslûb Örneği: Abdü’l-Kayyûm, “İmam Gazzâlî̀nin Mektupları” Adı Eserinin Değerlendirmesi
}

\section{The Language / Style Example of the Ulama in the Middle Ages against Power: Abd al-Qayyum, The Evaluation of the Work "Imam Gazzali's Letters"}

Hatice Güler ${ }^{\mathrm{a}^{*}}$

a Öğr. Gör. Dr. Kırşehir Ahi Evran Üniversitesi, Atatürk İlkeleri ve İnkılâp Tarihi Bölümü, Kırşehir/Türkiye.

ORCID: 0000-0002-8544-2734

\section{MAKALE BİLGISİ}

\section{Makale Geçmişi:}

Başvuru tarihi: 16 Ağustos 2018

Düzeltme tarihi: 28 Ekim 2018

Kabul tarihi: 07 Ocak 2019

\section{Anahtar Kelimeler:}

İktidar

Gazzâlî

Mektup

Üslûb

Tavsiye

Eleştiri

\section{ARTICLE INFO}

\section{Article History:}

Received: 16 August 2018

Received In Revised Form : 28 October 2018

Accepted : 07 January 2019

\section{Keywords:}

Power

Gazzâlî

Letter

Style

Advice

Criticism
ÖZ

İmam Gazzâlî’nin Selçuklu hükümdarlarına, vezirlerine, veliahtlarına ve zamanının ilim insanlarına hitâben yazdığı mektupların toplandığı eser olan Abdü'l-Kayyûm tarafından hazırlanan İmam Gazzâlî'nin Mektupları, ortaçağda ulemânın iktidara hitâben kullandığı dil ve üslûbu anlatması bakımından mühimdir. Eserde iktidara gönderilen mektuplarda, gününün yenileyicisi olan ve zâlimlere boyun eğmeyi reddeden tam bir şuur yansıtılmaktadır. Bu mektuplar aynı zamanda, çağının olaylarını yansıtması bakımından da ilgi çekicidir. Gazzâlı’yi, Selçuklu hükümdarlarını, yetkililerini, kayırma, taraf tutma, adaletsizlik ve rüşvet gibi, o dönemde toplumun temel hastalıkları konusunda ikâz ettiği üslûbu incelendiği vakit bu mektuplara ilgi daha da artmaktadır. Tavsiyelerini sunarken âyet-i kerîmeler ve hadîs-i şerifler çerçevesinde hareket etmiştir. Bu çalışmada, iktidara karşı kullanılacak dile örnek teşkil etmesi açısından Abdü’l-Kayyûm’un “İmam Gazzâlî’nin Mektupları" adlı bu eserinin uslûbî değerlendirmesi yapılmıştır.

\section{A B S T R A C T}

Imam Gazzâlî's Letters of Imam Gazzâlî written by Abd al-Kayyûm, the work of Imam Gazzâlî's writings written to the Seljuk rulers, viziers, crown prince, and the scholars of time, are important in terms of the language and style used in the Middle Ages by the ruler. The letter in the work reflects a complete consciousness of refusing to bow to the zâlims, who are the renewers of the day. At the same time, these letters are also interesting in terms of reflecting the events of the time. Gazzâlî, Seljuk rulers, officials, such as favoritism, sides, injustice and bribery, at that time in the style of the basic diseases of society at that time when examined the interest in these letters is growing more and more interest. While presenting his recommendations, he has benefited much from verses and hadiths. In this declaration to be prepared by my person, the evaluation of the article named "Imam Gazzâlî's Letters" by Abd al-Kayyûm will be made in terms of constituting an example to the language to be used against power.

\section{Giriş}

Türk-İslâm siyâset düşüncesinde başka hiçbir ismin onun kadar köklü bir iz bırakmadığı söylenen Gazzâlî, hem dinî düşünce hem de siyâset düşüncesi açısından odak noktası isimlerden birisi olmuştur. Onun tüm Türk-İslâm dünyasında ün bulmuş unvanı olan "Gazzâl” kelimesi "iplik eğiren” demektir. Çünkü Gazzâlî’nin babası iplikçi idi. O ise, büktüğü iplikleri Tus'taki dükkanında satardı. Öleceği zaman oğulları Muhammed ile Ahmed'i biriktirebildiği para ile birlikte bir Sûfi'ye onları okutması ricasıyla emanet etmiştir. Lakin

\footnotetext{
* Sorumlu yazar/Corresponding author

e-posta: haticeozkara9@gmail.com
} 
babalarının bıraktığı para kısa sürede bitmiştir. Sûfi, durumu iki kardeşe açıklamış ve medreseye sığınmaktan başka çare kalmadığını bildimiştir. İşte geleceğin meşhur Muhammed ve Ahmed Gazzâlî’leri Selçuklu medresesinin verdiği imkândan faydalanılarak topluma bu şekilde kazandırılmıştır (Köymen, 2011: 375-376; Hitti, 2011:584).

450/1058 senesinde Tûs şehrinde doğan Ebû Hamid elGazzâlî, Halife ile Sultan Melikşah (öl. h.485/m.1092) arasında elçilik görevi ile bürokrasi yaşamına başlamıştır. Fakat Bağdat'da Gazzâlî'nin bu gibi faaliyetleri çok sürmemiştir. H.488/m.1095 senesinde içine düştüğü bir şüphe bunalımı akabinde Bağdat'dan ayrılarak inzivaya çekilmeye karar vermiş iki sene kadar Şam'da sessiz bir hayat sürdürmüștür. Ancak İslâm ülkesinin her tarafında Bâtınî tehlikesi varken Gazzâlî'nin Bağdat'ta nefsini 1slah edebileceği tezi mantığa uygun görünmemektedir. Çünkü sûfilerin yoluna sülûk etmek için Allah'tan gayrı her şeyden yüz çevirme düşüncesi ağır basmaktadır. Bunun tatbîki; mal, mülk, şöhret, mevkî, dünyevî saadet ve zevkler içinde olmamalıdır. Sözkonusu felsefeden hareketle Gazzâlî'nin inzivasının bu hedefe hizmet ettiği düşünülmektedir (Çubukçu, 1964: 87).

Gazzâlı̂’nin münzevî süreci, hayatının geri kalanının tohumlarının atılmasındaki etkenlerden biri olmuştur. Gazzâlî’nin ahlâkî gelişim söz konusu olduğunda "uzlet"i tavsiye etmezken "Bu devirde taassuplardan, tartışma ve mücadelelerden styrllmış memleket neredeyse yoktur. Bu buhranlardan selâmete çıkmanın çaresi ancak uzlette olmaktır." diyerek "uzlet" i ve "sükût" u tavsiye etmesi sosyolojik bakımdan üzerinde durulması gereken bir konudur (Çelikel, 2011: 146). İnzivadaki bu süreci Kudüs'e gitmesi takip etmiştir. Hz. İbrahim'in mezarını ziyaret ederek burada sultanların yanına gitmemek, münazara yapmamak ve taassup göstermemek, sultanlardan maddi yardım almamak hususları üzerine yemin etmiştir (Çubukçu, 1964: 60). Zaman zaman felsefî, psikolojik tahlillere girişmiş ve iç gözlemlerde bulunmuştur (Şeşen, 1990: 371). Değerli öğrencilerini açıktan açığa takdir etmekten çekinmeyen İmâmü'l-Haremeyn Cüveynî, talebeliği sürecinde keskin zekâsı, kavrayışı, kuvvetli hafızası ile temâyüz eden Gazzâlî’yi, coşkun denize benzetmiştir (Köymen, 2011: 374;378).

Mağrib'e varana dek İslâm dünyasının her tarafinı düşünce/felsefe şemsiyesi altına alan (Şeşen, 1990: 371) Gazzâlî, Bağdat'da baş eseri olan İhyâ-i Ulûmi'd-Dîn adlı kitabını telif etmiştir. Bu eserin sahip olduğu tasavvufî hava, şer'î hukuku canlandırdı. Bir başka deyişle şer'̂̂ hukukun sünnî esaslara göre şekillenmesinde rol oynadı ve İslâm doktrinini mayalandırıp sağlamlaştırdı.

Bu eserde ve yine onun Fâtihatü'l-Ulûm ve Tehâfütu'lFelâsife, el-íktisâd fi'l-I'tikâd adını taşıyan aynı mahiyetteki eserleri sayesinde sünnî düşünce sistemi en yüksek noktasına varmıştır. Latince'ye kısmen de olsa 1150 senesinden evvel çevrilen bu eserler, Yahudi ve Hristiyan Skolastizmi'nde gözle görülür tesirler oluşturmuşlardır. Hristiyan ilâhiyatçılardan Thomas d'Aquinas ve daha sonra Paskal, el-Gazzâlî'nin ortaya koyduğu fikir ve düşüncelerin dolaylı bir şekilde tesiri altında kalmışlardır; böylece $\mathrm{O}$, batı dünyasında gelişen Hristiyan görüşlerin altına imzasını atabilecek İslâm düşünürlerinin en ziyade hak sahibi olanlarından biri olmuştur. El-Eş'âri ve elGazzâlî tarafından tesis edilen Skolastik düşünce yapısı, İslâm'ı günümüze kadar taşıyıp getirmiştir (Hitti, 2011:586).
Kendisi için bir dönüm noktası olan başlangıcı Nizâmiye medresesinde, dört y1l süreyle (1091-1095) dersler vermek suretiyle yapmıştır. İhyâ adlı eserine giriş mahiyetinde yerleştirdiği öğretimle ilgili bölümde eğitimin asıl gayesinin talebeye ilim öğretmek şeklindeki fikre şiddetle karşı çıkmakta ve bunun aksine, talebeyi ahlâkî ve mânevî bir sistem ile organik bir bütünlük ve ilişki içinde olduğunu İslamda ilk olarak ortaya atan müellif olmaktadır (Hitti, 2011: 559). Başka bir ifade ile "Hâkim sinıfin memuru" olarak "devletin ideolojik aygıtı” olan medresede Nizâmülmülk'ün ölümüne kadar mühim bir rol üstlenen Gazzâlî, "abartı ve olumlu olmayan siyaset ile iç savaşların sebebiyet verdiği bir atmosferden etkilenmeden edemeyecek kadar hassas ruha sahip" biri olarak şöhret bulmuştur (Çelikel, 2011: 150).

Gazzâlî, mistiko-psikolojik üslûba giren ahlâk kitaplarının mümessilidir. İslâmi muhitte revaçta tutulan bütün ahlâkî felsefe sisteminde tevekkül, kanaat ve sabır gibi bazı erdemler pek değerli tutulmuşlardır. Ahlâk felsefecisi nazarında insana has kusur ve noksanlar adeta bir tabip gibi, ruhun hastalıkları olarak teşhis edilmiş ve öylece gösterilmişlerdi; onlara göre faziletlerin bu şekilde sınıflandırılması, ruhun sahip olduğu melekelerin analize tâbi tutulması esasına dayalıdır ve ruhun her bir melekesi, kendine has bir fazilete ve kendine has bir kusura sahiptir (Hitti, 2011:547).

IV-VI/X-XII. yüzyıl zarfında İslâm coğrafyasının doğu yakasında yaşanan siyâsî gelişmeleri mercek altına aldığımızda, Abbâsî hanedan (750-1258) üyeleri arasında yaşanan halifelik mücâdelelerinin kamu düzenini olumsuz etkilediğini görmekteyiz. Ardından Büveyhîlerin (932-1157) etkin bir siyâsî güç olarak tarih sahnesinde yerini alması bölgede huzur ve istikrârın sağlanmasını geciktirmiştir (Yazar, 2009: 151). Böyle bir zamanda Selçuklu sultanları İslâm devletinin her zaman bayraktarlığını ve hâmiliğini yaparak bu uğurda hâricî ve dâhili birçok savaşlara iştirak etmiş ve zaferler kazanmışlardır. Selçukluların İslâma olan hizmetleri devrin büyük âlimi Gazzâlî’nin dikkatinden kaçmamış, yeri geldiğinde sultanları irşad ve yeri geldiğinde de ikaz etmiştir. Takdire şayandır ki, büyük bir devlet adamı olan bu sultanlar, o büyük âlimi her iki halde de anlayışla karşılamışlar, devlet adamlığına yakışır bir tarzda O'na saygı göstermişlerdir. Gazzâlî’nin Selçuklu Türkleri ve sultanları ile olan bu münasebetleri, O’nu bu necib millet hakkında görüş beyan etmeye sevk etmiştir. Gazzâlî ömrünün son dönemlerinde yazdığı eserlerinde, Türkler hakkındaki kanaatlerini belirtmesi, onun bu husustaki görüşlerinin uzun bir tarihî tecrübe ve müşâhedenin mahsûlü olduğu neticesini vermektedir (Korkmaz, 1995: 83-84).

Gazzâlî’nin çok sayıda yayınlanmış mektubu, Arapça ve Farsça olarak yazılan Tabakâtü'ş-Şâfiiyyeti'l-Kübrâ, Mecmaü'l-İnşâ ve Âsâru'l-Vüzerâ gibi kitaplarda dağınık bir şekilde yer almaktadır. Mektuplarının en önemli koleksiyonu ise Farsça kaleme alınan Fezâilü'l-Enâm min Resâil-i Hüccetü'l-İslâm isimli eserde toplanmıştır. Ortaçağda ulemânın iktidara kullandığı dil bağlamında incelediğimiz Abdül Kayyum'un Gazzâlî'nin mektupları kitabı bu eserdeki mektupların tam metin halinde tercümesidir. El yazması İstanbul Üniversitesi Kütüphanesi ile Süleymaniye Kütüphanesi'nde mevcut olup İngilizce çevirisinde esas alındığı belirtilen nüsha (Abdu'l-Kayyûm, Letters of $\mathrm{Al}$ - 
Ghazzali, Kitab Bhavan, India, 1992) İstanbul Üniversitesi Kütüphanesi'ndeki yazmadır.

\section{Gazzâlî’nin Mektuplarında İslâm-Siyâset İlişkisi}

Gazzâlî’nin Mektupları'nda siyâsetin nasıl yaşandığını, siyasal hareketlerin ve değişimlerin İ́slâmî terimlerle nasıl algılanıp ifade edildiğini daha kolay anlamak için, her şeyden önce, Müslümanlar arasındaki siyasal söylemin dilini, sözcüklerin nasıl kullanılıp anlaşıldığını, bütün bir siyasal iletişimin gerekli bir bölümü olan eğretileme ve imâların çerçevesinin nasıl oluştuğunu kavramak mühimdir. Bunu yapabilmek için ise, Müslüman dünyasının son yüz, yüz elli senedir önemli ölçüde dış dünya tarafindan etkilenen, hatta bozulan bugünkü siyasal hayattaki dil kullanımının ardına uzanılması gerekir (Lewis, 2011: 17).

İnsanlık, tarihsel ve siyâsî tecrübelerine rağmen, bütün zamanlar için geçerli olacak devlet biçimleri ve yönetim şekilleri geliştirememiştir. Her devlet biçimi ve her yönetim tipi, ortaya çıktığı çağın şartlarından etkilenir ve hatta bir anlamda ondan doğar. Her tarihsel çağın gerçekleştirmek üzere kendine koyduğu "ideler" vardır. Ortaçağ için bu ide, insanlığ 1 bir dinsel ethos altında evrensel bir devlet idealinde birleştirmekti. Gazzâlî’nin Mektupları'nda yansıtılan İslâm siyâset tecrübesinde görülen veya en azından teorik olarak kabul edilen bir başka husus da devletin bizzat değer belirleyici olmayıp, ulemânın şahsında temsil edilen sivil toplumun ürettiği değerlerin yaşanır hale getirilmesinde aracı konumda olduğudur. Bu bağlamda ulemânın her yerde hazır ve nâzır olması sebebiyle sosyal tarihçi için ulemâ bahsi cezbedici bir konu olmuştur. Ulemâdan hareketle toplumun geriye kalan kısmı hakkında genellemeler yapılacağını söylemek yanıltıcıdır; ama onların davranışlarının kesin, eleştirel bir bilgisini, aksi halde tamamen karanlıkta kalacak bir toplumsal sistemin dar geçitlerine ve uzak köşelerine 1 şık tutmak için kullanılabilir. Onların birbirlerini ve ulemâ olmayanları nasıl gördüklerini inceleyerek, genel anlamda Ortaçağ Müslümanları için mümkün olan toplumsal davranış kalıplarının daha anlamlı bir haritası çıkarılabilir (Hitti, 2011: 234).

İslâm dininin en belirgin ve temel niteliklerinden biri hem dünya hem ahiret dini oluşudur. Bundan dolayıdır ki $\mathrm{Hz}$. Peygamber Medine'ye hicret eder etmez, yalnız dar anlamda bir din önderi değil, aynı zamanda siyâsî bir lider olarak davranmıştır. Medine'deki Müslüman olan ve olmayan bütün unsurların benimsediği bir anayasal belge hazırlayarak dinin öngördüğü ilke ve hedeflerle uyumlu bir siyâsî yapı oluşturmaya başlamıştır. Siyâset mesleğinin zaman zaman bazı toplumlarda ahlâk ilkelerinin dışına saptırılarak değer aşınmasına uğratılmasını ârızî bir durum olarak değerlendirmek gerekir. Nitekim bizzat Hz. Peygamber ve ashabının önde gelenleri olan Hz. Ebubekir, Hz. Ömer, Hz. Osman ve Hz. Ali'nin birer siyâsî lider oldukları göz önüne alındığında İslâm'da siyâsetin ne kadar yüce bir meslek ve uğraşı olduğu açıkça ortaya çıkmaktadır. Bu durumu dikkate alan İslâm bilgin ve düşünürleri, genellikle siyâsete hem toplumsal faaliyet hem de bir bilim dalı olarak büyük önem vermişler ve onu mesleklerin en şereflisi saymışlardır. İslâmî ilimlerden fikhın önemli bir kısmını siyâset konuları oluşturur. Genel fikıh kitaplarından ayrı olarak İslâm hukuk literatürü içinde "el-Ahkâmü's-Sultâniyye" (Mâverdî, el-Ahkâmü'sSultâniyye ve'l-Vilâyetü'd-Diniyye, Beyrut, 1985; Ebû Ya'lâ, el-Ahkâmü's-Sultâniyye (nşr. Muhammed Hâmid el-Fakkî),
Kâhire, 1938) ve benzeri eser türlerinin yer alması, fikıh bilginlerinin siyâset konusunu kendi ilgi alanları içinde görmüş olmalarının önemli bir delilidir. İslâm düşünürleri, bilhassa Fârâbî̀den itibaren İslâm kültür tarihi bakımından büyük değer taşıyan, oldukça orijinal bir siyâset felsefesi geliştirmişlerdir. Bütün İslâm bilginleri siyâseti, insanın toplumsal bir varlık olmasının sonucu sayarlar. Bunlardan Gazzâlî, mektuplarında siyâseti özellikle iki açıdan gerekli görmüştür:

Öncelikle siyâset doğal ve toplumsal zorunluluğun bir sonucudur. Şöyle ki; insanlar, yalnız başlarına altından kalkamayacakları çoklukta ihtiyaçlarla yüklüdürler. Bu durum insanların birlikte yaşamalarını zorunlu kılar. Ancak bu birliktelik sürtüşme ve çekişmelere de yol açar. İşte ihtiyaçların-çekişmelere yol açmayacak şekilde- barış, güvenlik ve adalet içinde karşılanması ancak siyâset denilen yapılanmayla mümkün olur. Müellif el-Cüveynî de Atebetü'lKetebe adlı eserinde devlet siyâsetinin temellerini belirlerken birinci sıraya adaleti, sonra şeriat esasları ile saygıdeğer ve kıymetli insanların haklarının korunmasını koymaktadır. Kısacası ideolojik siyâsî fikirlere o devrin devleti, genel itibariyle adâlete, sultandan en alt sınıftaki memura kadar herkesin takip etmesi gereken yola dayanmaktadır. Sonuç olarak Gazzâlî, siyâsetin ahlâkî boyutuna işaret etmiş olur. Büyük Selçuklu veziri Fahrülmülk Ebu'l-Fethi'l-Muzaffer Ali b. Nizâmülmülk Hazretlerine (1042-1106) hitâben yazdığı satırlarda şu şekilde ifadeler yer almaktadır: "Selçuklu devletinin baş vezirlik makamına geldiğinizi duyduğumda hissettiğim memnuniyeti bilemezsiniz. Bu satırlart da tebrik etmek ve bu vesileyle riya, yalan-dolan ve ahlâksızlikla dolu bu dünya hayatı hakkında sizi ikaz etmek için yazıyorum. Devlet için dualar ettikten sonra, hükümdarlarl, sultanları ve vezirleri ikaz etmek, dervişlerin mukaddes bir vazifesidir. Ben de bir İslâm âlimi ve bir derviş olarak, bu mektubu yazmış olmakla vazifemi yerine getirdiğimi düşünerek mutlu oluyorum " (Abdü'l-Kayyûm, 1982: 46).

İkinci olarak ise; siyâset, dinî hayatın yürütülmesi için de gereklidir. Çünkü dünya işlerinin düzgün ve sağlıklı işlemediği yerde dinî ödevler de aksar. Bu suretle toplumda huzur ve güvenliği sağlayan siyâset, bireylerin dini yükümlülüklerini yerine getirebilmeleri için rahat bir ortam hazırlamış olur. Siyâsetin din ve dünya hayatına bu hizmeti dolayısıyla İslâm bilginleri, adaletle yürütülen siyâseti üstün bir ibadet saymışlardır. Haşmetli Sultan Sencer hazretlerine; bu ebedî sultanlığa mâlik olmak, bütün cihan halkı için güç ise de Doğu'nun sultanı için güç değil, kolaydır şeklinde başlayan hitabına Peygamber Efendimiz'in (s.a.v) sözleriyle devam etmiştir: "Bir günlük adalet icrasl, altmış yıl ibadetten üstündür." (Cüveynî, 1329hş: 74). Mâdemki Allah diğerlerinin altmış yılda kazanabileceğini senin bir günde kazanman için eline vasıta ve sebep vermiş, bundan daha büyük bir devlet ve başarı olur mu? (Abdü'l-Kayyûm, 1982: 46) sözü ile mektubunda devlet-nimet perspektifindeki görüşünü dile getirmiştir.

\section{Gazzâlî’nin Mektuplarına Göre Yöneticinin Bazı Nitelikleri ve Görevleri}

\subsection{Sultanın Şahsında Olması Gereken Özellikler}

Hükümdarlık kesbî değil, vehbîdir; yaratma sadece Allah'a aittir. İnsan sadece fiili elde etme kudretine sahiptir. Allah 
yaratır kul ise kesb eder, dolayısıyla Allah'ın kulun kesb kudretine müdahalesi yoktur. Başka bir deyişle İnsanın fiili gerçekleştirme noktasındaki işlevini Gazzâlî, "kesb” kavramı ile ifade etmektedir. Güç yetirilen nesnenin kula nispetine "kesb" adını vermektedir (Çubukçu vd, 1962: 60).

Bağdat'da okunan hutbede sultan olarak zikredilen ismin sürekli değişmesi neticesinde yaşanan belirsizlik durumu, ortaya çıkan bütün problemlerin ana kaynağı olarak görülebilir. Böyle bir atmosferde hükümdarın Allah'ın yeryüzündeki gölgesi olarak kabul edilmesi, onun meşrû'iyetini sorgulanamaz hale getirecektir. $\mathrm{Bu}$ anlayışa göre hükümdarın sorgulanmaması ve yeni arayışlar içerisine girilmemesi de düzen ve istikrârın teminâtı olacaktır. Hükümdarın halkı idare etmek için birtakım meziyetlere hâiz olması hayâtî önem arz etmektedir (Gazzâlî, 1969: 8)

Halkı idare etmek için hükümdarın sahip olması gereken meziyetlerin olgunlaşması âlimlerle irtibat kurma ile mümkün olmaktadır. Gazzâlî, tek başına, bilenlerle istişârede bulunulmadan yapılan idârî tasarrufları hoș karşılamamış ve âlim müşâvirleri, devleti idare edenler için zorunlu görmüştür. Âlimin, iyi niyetli âdil bir idareciye ilmî yardımda bulunması, gayr-i âdil bir idareciden de uzak durması, onun için bir görevdir (Korkmaz, 1995: 82).

Âlimlerin, idarecilerle, devlet başkanlarıyla olan irtibatı, dua, methiye nasihat ve halkın ihtiyaçlarını giderme şeklinde kendini göstermektedir. Ortaçağ İslâm yazısının sadece birkaç türü -medhiye, yöneticilere nasihatler, siyâsi polemikleraçıkça kendilerini propaganda- yani bir ideolojinin taşınması ya da güçlendirilmesi için araç- olarak tanımlarlar. Saflık ve aşırı eleştiri (hypercriticism) şeklindeki çifte risk sadece bizim uyarılmışlı̆̆ımız ve

duyarlılığımızı arttırmalıdır (Humpreys, 2004: 193). Gazzâlî, mülâkat türlerinden olan duaya çok büyük önem verir ve özellikle mazlumların duasının icabetle sonuçlanacağını belirtir. Devlet başkanına gıyâbında yapılan dualar hoş karşılanırken, yüzüne karşı yapılanlar aynı şekilde değerlendirilmemiştir. Zira Gazzâlî’ye göre, vicâhî dualarda çoğu kez ihlasın ötesinde riyâ karışımı söz konusudur (Korkmaz, 1995: 77). Demek oluyor ki Gazzâlî, bir yandan idarecilerin, âlimler tarafından ikaz ve irşad edilmesini gerekli görürken, öte yandan onlarla, çok sık1 ilişkiler içerisinde olmayı da uygun bulmamıştır. Zira gereksiz yere hükümdarlarla birlikte olmaya çalışan ve birlikte olanlar, riyâkâr olur ve onların isteği doğrultusunda görüş beyan ederler (Korkmaz, 1995: 79)

\subsubsection{Ehliyet ve Liyâkat}

Hz. Peygamberimiz, "İş, ehlinden başkasına verildiği zaman klyâmeti bekle" buyurmuştur. Bu hadîs-i şerif, siyâsette ehliyetin önemini açık bir şekilde göstermektedir. Kur'ân-1 Kerim Sûre-i Nisâ, 59. âyet-i kerimede devlet adamları için "ulü'l-emr" ifadesi kullanılmıștır. Bu sebeple İslâm bilginleri, eserlerinde siyâsî ve idârî görevlere getirilecek kişilerde aranması gereken niteliklere geniş yer vermişlerdir. Bunlardan Fârâbî, ideal bir devlet başkanında bulunması gereken beden sağlığı ve kusursuzluğu, anlama ve kavrama üstünlüğü, güçlü hafıza, güçlü zekâ, etkili hitâbet, öğrenme sevgisi ve yeteneği, mideye düşkün olmama, doğruluk sevgisi, cömertlik ve ikram sevgisi, tok gözlülük, azim ve kararlılık gibi başlıca nitelikleri sıralamıştır (Farâbî, 1956: 88-89). Benzer şartlar Gazzâlî tarafından da sıralanmıştır.
Gazzâlî’ye göre siyâsette liyâkat kaygısını en çok duyması gereken kişi, bu görevi üstlenecek olandır. Çünkü siyâsî makamda bulunan kimse, kontrolü elinde tutmak ve genel düzeni sağlamak için, başka mesleklerde bulunanlara hâkim olması; insanları dünya ve ahirette kendilerini mutlu kılacak en doğru yola yöneltmesi gereken insandır. Bu yüzden siyâset mesleği, şerefli olduğu kadar tehlikelidir. Bir toplumda sevginin yaygınlaşması, adaletin gerçekleşmesi ve haksız güç kullanımının ortadan kalkması ancak o toplumda yönetimin faziletli insanların elinde bulunmasıyla mümkün olur. Onun için Fârâbî şöyle der: "Bir faziletli insan öldüğü veya öldürüldüğü zaman insanlar ona ağlamasın; asıl onu kaybeden ülke halkına ağlasın!"

\subsubsection{Adalet ve Dürüstlük}

Siyâset mesleğinde adalet ve dürüstlük bütün faziletlerin başında gelmektedir. Nitekim tarih boyunca ve bütün toplumlarda devletin işlevleri içinde en önemlilerinin adâlet ve dürüstlük olduğu düşünülmüştür. Toplumun bekâsının teminâtı olan adalet, öncelikle bir devlet işlevidir. Maverdî'nin de belirttiği gibi herkesi kucaklayan bir adalet uygulaması, fertleri kaynaşmaya ve her bakımdan saygıya sevk eder (Mâverdî, 1978: 141). Ayrıca ancak kapsamlı bir adaletle ülke mamur olur; iktisâdî gelişme gerçekleşir ve devlet güvencede olur. Maverdî, "Bir ülkeyi zulüm kadar tahrip edebilecek başka hiçbir şey yoktur” diyerek ülkedeki bütün bozukluklarda adaletsizliğin mutlaka bir payının ve etkisinin bulunduğunu ifade ederken evrensel bir gözlemi dile getirmiştir. Bu yüzden İslâm bilginleri adâleti, insanın bizzat kendisine karşı âdil olmasından başlayarak bütün ülkeye dalga dalga yayılması gereken bir rahmet gibi görürler.

İnsan vücudu ile devletin bünyesi arasında sıkı bir ilgi gören Gazzâlî, tabibi insan için, fakihi de devlet için lüzûmlu görmektedir. O, bedenin devamının tıbbi imtizaç kanununa, devletin devamının da hakkâniyet kurallarına ve âdil muameleye göre mümkün olacağını belirten (Korkmaz, 1995: 79). Nizâmüddin Fahrülmülk hazretlerine hitâben; "Sultan adına adaleti tesis etmeniz gerektiği zaman kendinizi, hakkı gasp edilmiş ve sultanın şikâyetini dinleyip hakkını iade etmesini bekleyen siradan biri gibi görün. Kendinizi halktan kesinlikle farkl görmeyin." diyerek son olarak adalet ve hakkâniyetle ilgili olan her şeyde üç haslet olması gerektiğini belirtmiştir (Abdü'l-Kayyûm, 1982, s. 45).

Adil olmayan bir hükümdarın mahkemelerinde adalet aramak, hukukun gerektirdiği cezaların verilmesini istemek, emirden ya da onun kolluk güçlerinden zararın tazminini sağlamalarını istemek, onların atadığı memurlara ve askerlerine, her şeye kâdir Allah'a itaatsizlik halleri dışında boyun eğmek gerekir demektedirler. Aynı görüşleri, daha keskin ve daha inanmış bir ifadeyle, din bilimci ve filozof Gazzâlî de savunmuştur. Gazzâlî’nin yazdıkları şöyledir: “Bizim burada beyan ettiğimiz rızamız, irademizle oluşmuş değil; zorunluluğun yasaklanmış olan şeyleri bile meşrû kılmasındandır." (Lewis, 2011: 151)

\subsubsection{Dinî Emir ve Yasaklara Uyma}

İslâm düşüncesi akımlarının kesiştiği yerde bulunurken de salt bir düşünür olmasının yanında bir din savunucusu olan Gazzâlî, "Hüccetü'l-İslâm” rolünü üstlenmiştir ki İslâm bilginleri ulemâyı şahsına ve ilmine güvenilen "hüccet", dil ve mantığ 1 iyi kullanan "hicâc" ve kendine yenik düşen "mahcĥc" 
olmak üzere üç sınıfa ayırmışlardır (Kaya, 2014: 410). Bu anlamda İslâm düşüncesinde Gazzâlî' den başka, belli bir ekole girmeden çok derin tesir bırakan bir başka düşünür bulamayız. Gazzâlî’ye kelâm ilminde bir dönüm noktası olmayı sağlayan, O’nu felsefenin büyük bir tenkitçisi yapan, bilginin imkânını ve temellerini yoklamaya sevk eden kısaca, zamanının bütün zihnî meselelerine el atmaya sevk eden sebepler olmalıdır. Çünkü hiçbir büyük düşünür ve fillozof rasgele teoriler kurmaz, yani hiçbir yüksek düşünce ve fikrî teori sırf kendisi için kurulmaz. Açık bir şekilde söylenebilir ki; bir düşünürü, sıradan insandan ayıran husus sahip olduğu "zihnî terbiye" vesilesiyle kazandığ1 düşünme metodudur (Güngör, 2003: 254-255).

Bu prensibi düşünürümüze uyguladığımızda O'nu da çağının zihnî ve itikâdî problemleriyle dolu olarak buluruz. Gerçi onun döneminin yoğun siyâsî kargaşalıklara rağmen bir iman buhranı içinde olduğu söylenemez fakat İslâm düşüncesinin bütün disiplinleriyle kemâle ulaştığı, kelâm, felsefe ve tasavvufun olabilecek bütün problemlerinin ortaya çıktığı bir dönem olduğu da ortadadır. Yani, çözülmüş problemlerle çözülmemiş olanlar ve dolayısıyla çözüm bekleyenler iyice belirmiştir. İşte Gazzâlî, bu çok çeşitli problemleri çözmeyi, İslâm düşüncesi ve imanın bütünlüğünü kurma görevini yüklenmiş bir düşünür olarak karşımıza çıkmaktadır.

Gazzâlî’nin mektubundaki Nizâmüddin Fahrülmülk hazretlerine hitâben; "Efendim, tüm gayretinizle Allâhü Teâlâ'nın emirlerini yerine getirmeye çalışmanızı, dünyevî şehvet ve kibir hastalığına yakalanmış kişilerle alakayı kesmenizi bütün samimiyetimle niyâz ediyorum. Putlardan tam kurtuluş ancak Allah'a tam bağlllıkla olur. Manevî tefekkürle kendi sinırl "ben”inizi unutup yüksek "ben"inizdeki ideal güzelliği görünceye kadar yükseleceksiniz.” (Abdü'l-Kayyûm, 1982: 30) satırlarından da anlaşılacağı üzere sağlam ve sıhhatli bir idârî mekanizmanın tesisi için idarecilerin âlimlerle teşrîki mesâi içinde olmalarını zorunlu görmektedir. Peygamber efendimizin "Gerçek saygıdan ayrılmak istemiyorsanız, hâkimlik vazifesini sorumlu, dürüst ve takva sahibi insanlara vermelisiniz." sözünü hatırlatarak Peygamber yolunun öbür dünyayı düşünmeyen idarecilerden çok farklı olduğunu, hâkimin başlıca vazifelerinden birinin yetimlerin malını korumak olduğunu belirtmiştir (Abdü’l-Kayyûm, 1982: 30).

İlk dönemlerde yaşayan âlimlerin ihlaslı ve metanetli olduklarını, ancak daha sonraları genelde maddi tamah peşinde koştuklarını ifade eden Gazzâlî, Hz. Ali’ye atfedilen "Başlangıçta halk uyuyordu âlimler uyanıktı, bugün ise âlimler uykuda, halk ölüdür. Uykudakinin sözünün ölüye faydası olmaz." sözünün, kendi zamanı için de geçerli olduğunu söyler. Ayrıca yapılan nasihatlerin sonuçsuz kalmasını da, âlimlerin ve halkın gerekli ihlasa sahip olmamasına bağlamıştır (Korkmaz, 1995: 82).

\subsubsection{Ihtiyaçları Giderme}

Halkın ihtiyaçlarını sultana iletmekten hiçbir zaman geri durmayan Gazzâlî, bunun âlim için önemli bir görev olduğunu, mektuplarında açık bir şekilde belirtmiştir. Meselâ, Gazzâlî, İbrahim es-Sebbâk (öl. h.513/m.1120) hakkında Nizâmüddin Fahrü'l-Mülk'e yazdığı mektubunda “...Duadan sonra, âlimlerin, halkın ihtiyaçlarının sultanlar tarafindan karşılanmasını istemeleri, âlimler için en büyük hediyedir. Cürcan şehri, uzun bir müddetten beri kendisine uyulacak bir âlimden mahrumdur. Simdi ise oraya büyük âlim İbrahim esSebbâk gitmiştir. O beldeyi ilmiyle ve takvastyla ihyâ etmiştir. Ancak o beldede onun aleyhinde faaliyete geçen din düşmanları ortaya çıkmıştır. Hakkında sana yalan beyanda bulunan bu fesat kimselerin sözlerine itibar etmeyiniz. Kendisini hizmete adayan büyük âlim Sebbâk'ı himayenize alınız" şeklinde ikâzda bulunmuştur (Korkmaz, 1995: 78-79).

Selçuklu Veziri Şihâbü'l-İslâm Ebu'l-Mehâsin Abdürrezzak bin Nizâmülmülk (1119-1121) hazretlerine hitâben; "Zâtiâlinizin böyle dardaki insanlarl rahatlatacak güzel ve hayırlı işleri ifâda elinden geleni yapmasını niyaz ediyorum (Abdü'l-Kayyûm, 1982: 62). Bu mektubu size eski bir dostumu tanıtmak amacıyla yazdım. Kendisi bir tasavvuf cemaatinin şeyhi olup, bağlllarl da kendilerini Allah yolunda vakfetmişlerdir. Kendisi yaşlı olup hayatını kazanamayacak durumdadır. Kendisine cennetin sırlarının açıldı̆̆ını söyleyen Ebu Bekr Abdullah onu, size mektup yazıp tanıtmamı ve mâlî sıkıntıları için yardımınızı ricâ etmemi tavsiye etti." (Abdü'lKayyûm, 1982: 65) Selçuklu Veziri Ebû Nasr Ahmed bin Nizâmülmülk İshak bin Ali ibn İshak (1107-1110) hazretlerine hitâben; "Eğger bir tek dinî vecibeyi yerine getirmekte zaaf gösterir veya geceleri çok derin uyursanı veya büyük bir günah işlemekle suçlanırsanız veya geniş topraklarınızda yaşayan bir tek köylünün bir gece aç uyuduğunu duyarsanız, Allah'ın gazabının size ulaşacağını ve geri kalan günlerinizi, bu vurdumduymazlı̆̆ınıza dövünerek geçirmek mecburiyetinde kalacağınızı hatırlayınız. Bir İslâm devletinin vezirliğini üstlenen kimsenin tecrübelerini, meselelerini, korku ve üzüntülerini düşünmek durumundasınız." (Abdü'l-Kayyûm, 1982: 55) şeklindeki üslûbu ise oldukça dikkat çekicidir.

Dönemin atmosferinde savaşların ne kadar mühim olduğunu tarihle haşır neşir olan her araştırıcı pekala bilmektedir. Gazzâlî'nin devlet yöneticilerine düşmanı etkisiz hale getirme noktasındaki tavsiyeleri yabana atılmamalıdır. Bu konuyla alakalı olarak Nizâmüddin Fahrülmülk hazretlerine; her devletin düşmanın saldırdığı acil durumlarda kalelerini korumaya çalıştığını belirtmiştir. Bazı devlet adamlarının, yağız atların, güzel savaş arabalarının ve altınların saldırganları zararsız hale getireceğini ve en iyi savunma gücünün yeterli kılıç ve silahlarla teçhiz edilmiş mahallî kuvvetler olduğunu düşündüklerini anlatıp diğer bazı devlet adamlarının da maddi kaynakları yerinde olan, pahalı ve yüksek kaleler inşa eden devletlerin, düşmanı başarıyla durduracağını söylediklerini ifade etmiştir (Abdü'l-Kayyûm, 1982: 36).

\subsubsection{Merhamet}

Esasında bu dünya hayatı bir yolculuktur. Ömür bir gemi, birlikte yaşayanlar da bu geminin yolcularıdır. Yolculukta yol arkadaşlarıyla iyi geçinmek ve onların hak ve hukukunu gözetmek lazımdır (Gazzâlî, 2004: 117). Buradaki mükellefiyetin ise üç temel prensibi vardır: Bunlardan birisi, kimseye zarar ve eziyet vermemektir. Allah Resûlü (s.a.v) şöyle buyurmuştur: "Müslüman, eliyle ve diliyle Müslümanlara zarar ve eziyet vermeyen kimsedir." İkincisi, herkese gücü nispetinde faydalı olmak ve onlara iyilik etmektir. Üçüncüsü ise onların kötülüklerine iyilikle karşılık vermektir (Gazzâlî, 2004: 120-121).

Gazzâlî, mektuplarında Bağdat vezirliğine atanan Mucirüddîn hazretlerine merhamet noktasında tavsiyeyi aşan ikâz 
boyutunda değerlendirmeler yapmıştır. $\mathrm{Bu}$ değerlendirmelerinden mühim olarak addettiklerimizi burada zikretmek yerinde olacaktır. Mucirüddîn hazretlerine hitâben; "Gelmiş geçmiş bütün vezirlerin en akıllısı olduğunuza göre, her şeye gösterilecek dikkatin, gerçek değerini ve hissesini bulacağına eminim. Bedeninizdeki bu terkibin çözüleceği, birbirinden ayrllıp başka bir yere yerleştirileceği günün uzak olmadığını unutmayınız. Tebaanıza müşfik olunuz ve onlara iyi davranınız. Masum insanlara zulmetmekten sakınınız, aksi halde Allah'ın indinde utancınız büyük olur. Bu cezadan kurtulmak istiyorsanız, manevî bir kahraman gibi, bu zâlim güçlerle mücâdele ediniz ve onların emirlerine uymayınız (Abdü'l-Kayyûm, 1982: 77) Sosyal adâleti sağlamada tez canlı olunuz. Tabiatla ahenk içinde yaşayabilmeniz için, temel faziletlerden olan irfanımızı, iyi ve güzelin bilgisini geliştirmemiz lâzımdır (Abdü'l-Kayyûm, 1982: 78). Aldatıcı olan bu hayatın tuză̆ına düşmemeniz için sizi ikaz ediyorum (Abdü'l-Kayyûm, 1982: 55) Bütün manevi hakikatlerin ışığında, her gün kendinize dikkatli bir şekilde bakmanızı ve sizi saptıran sebepleri bulmanız rica ediyorum. Sonra hatalarınızı düzeltin ki, fakir tebaanıza karşı adaleti tesis edemeseniz bile, en azından kendinizi usûlüyle idare etmeyi ögrenir ve vicdanınızın sesine kulak verirsiniz (Abdü'lKayyûm, 1982: 82). Görüldüğü üzere Gazzâlî, yöneticinin kendi düşünce ve davranışları doğru bir biçimde şekillenirse politikalarının da sağlıklı olacağını ve yönetimin de gelişip büyüyeceğini zımmen savunmaktadır. Ancak onun için dinin gerçekliği başattır; yöneticinin davranışının her bir veçhesi bu gerçekliğe kişisel bağlılıktan kaynaklanmalıdır (Humpreys, 2004: 208) Mucirüddîn Hazretlerine hitâben devam ederek; "Gerçekler her zaman acıdır ve kendisine söylenen acı şeylere tahammül gösterenler, manevi muvaffakiyetler elde etmekte zorlanmazlar. Çünkü bu yolla fevkalade bir nefs murâkabesi kabiliyeti kazanırlar (Abdü'l-Kayyûm, 1982: 83). Geçmiş vezirlerin hiç birinin, kötü amelleriyle sizin kadar dile düşmediğini belirtmeliyim. İdareniz neticesinde halkın çektiği sefâlet ve perişanlık hesaba gelmediği gibi siz hala ustırap içindeki Tus ahalisine acımıyorsunuz (Abdü'l-Kayyûm, 1982: 85) şeklinde tenbih de denilebilecek boyuta ulaşmış satırlar yazmaktan kendini alamamıştır.

Bununla birlikte bir hükümdar korkuyu öyle bir biçimde sağlamalıdır ki, kendisine sevgi duyulmasa da nefret edilen biri de olmamalıdır çünkü nefret uyandırmadan da korkulan biri olunabilir ki bir hükümdar bunu, vatandaşlarının mallarına ve karılarının iffetine göz dikmediği müddetçe başarabilir (Machiavelli, 2013: 113).

\subsubsection{Doğru Bilgiye Ulaşma Çabası}

Gazzâlî, İslâm düşüncesi tarihinde emsalinden radikal tutumu ile ayrılan bir düşünür olarak karşımıza çıkar. Ondaki bu özelliği belirleyen taraf ise bilgi anlayışında aranmalıdır. Öyle ki; "Ey devletli hükümdar! Bu faziletin bir adı da bilgi ve akıldır. Insan bilgisiz doğar ve yaşadıkça öğrenir; bilgi sahibi olunca her işinde muvaffak olur. Çalışmakla elde edilmeyen şey akıldır. Bilgisiz devlet sahibi olsa dahi elinden yitirir. Bilgili devlet sahibi olursa ülkesi huzura kavuşur. Bey bilgili ve akıllı olmalıdır." ifadesi bilgi ve bilgenin devlet için ne kadar elzem olduğunun göstergeleridir (Taylan, 1994: 19-20). Düşünürümüz ilimleri amelî ve nazarî ilimler diye taksim etmiştir. İnsan hemcinsiyle beraber yaşamaya mecbur olduğu için onun diğer insanlarla olan ilişkilerini düzenleyen bir ilim olmalıdır. Gazzâlî’ye göre bu ilmin esası İslâm şeriatındadır.
Mesela şehirlerin ve oralarda yaşayan halkın idaresini ele alan siyâset ilmi böyle bir ilimdir (Taylan, 1994: 34). Gazzâlî insanın bir tabi varlık yanının bulunduğunu kabul eder fakat onun ilahi varlık yanının bulunduğu fikrinden de hiç uzaklaşmaz. Onu insan yapan şeyin canlı olması, algılaması, aktivitesi ve reaksiyonları değil, düşünebilmesi, sorumlu olduğunu bilmesi ve ilâhî olanla karşı karşıya bulunduğunu hissedip idrak etmesidir (Taylan, 1994: 60).

Akıl ismi birkaç anlama gelen müşterek bir isimdir. Şu anlamlar için kullanılmaktadır: (Gazzâlî, 1994: 30).

i) Bazı zarûrî bilgiler anlamında

ii) İnsanı nazarî bilgileri kavramaya hazırlayan zihnî canlılık anlamında

iii) Tecrübe ile elde edilen bilgiler anlamında. Öyle ki tecrübelerin, bu yönüyle eğitip olgunlaştırdığ 1 kişiye akıllı denmez.

iv) Oturup kalkmasında, konuşmasında bir heybet, vakar ve sekîne bulunan kişi anlamında. Bu anlamda olmak üzere, "falan kişi akıllıdır" denir ve bununla onda bulunan sükûnet kastedilir.

v) Ameli ilimle birleştiren kişi anlamındadır. Bu yüzden bozguncu, son derece bilgili olsa bile ona ak1llı denilemez.

İnsan hem muhtar hem de mecbûrdur. İnsan, Allah'ın kendisi için halk ve takdir ettiği şeyi beğenip seçmek ve onu kendi istek ve iradesiyle fiil haline getirmek zorundadır. $\mathrm{Bu}$ zorunluluk, bu şeyin onun kendi akıl, fitrat ve mizaâcına en uygun şey olmasından dolayıdır. Bu sebeple Allah, bu şeyi kendisi için takdir etmiştir. Bu nedenle de, insan irade ve ihtiyarına rağmen mecbur, mecburiyetine rağmen de irade sahibi ve muhtardır. Fakat insanın iradesini Allah yönlendirdiği için, insan kendi başına bir etkinliğe sahip değildir (Gazzâlî, 2004: 236-237).

“Âlimin sürçmesiyle âlem sürçer” derken Gazzâlî, ulemâya toplumsal bir rol biçmekteydi ki bu, iyiliği yüceltmekten "emr-i ma'ruf" başka bir şey değildir. Kendi âlemindeki sürçmeyi tanımlarken ise sorunun temelde "insan" la ilgili olduğunu dile getirmiştir (Çelikel, 2011: 138).

Daima her şeyi mükemmel bir iyilik standardında tutmak isteyen kişi kötülüklerin arasında kaybolur gider. Bu nedenle varlığını sürdürmek isteyen bir hükümdarın koşulların gerektirdiği gibi davranıp, ne zaman iyi ne zaman kötü olacağını öğrenmesi gerekir. Bunu da ancak aklını kullanma yoluyla yapabilir (Machiavelli, 2013: 104-105).

Mektuplarında vezirlerden birisine kendisini bir düşmanı inceler gibi gözlemci bir gözle takip etmesini tavsiye ederek, ihtiraslarını idare etmesini aksi takdirde vicdanının sesine kulak vermeyi öğrenemeyeceğini ve başkalarını hiç idare edemeyeceğini belirtmiştir (Abdü'l-Kayyûm, 1982: 39). Zira, bir hükümdar inanmak ve harekete geçmekte aceleci davranmamalı, korkusunu dişa vurmadan ihtiyat ve insaniyetle llımlı bir tavır takınarak adım atmalıdır ki gereğinden fazla kendine güven onu tedbirsiz, gereğinden fazla güvensizlik ise onu katlanılmaz birine dönüştürmesin (Machiavelli, 2013: 112).

Sûfîlerin eserlerinde, entelektüel üstü bir bilginin ve ifadenin, herkesin onu entelektüel bir tarzda yorumlayabileceği veya yorumlanması gerektiği garip bir etkileşim görülür. $\mathrm{Bu}$ 
tasavvufî edebiyattaki paradokslardan biridir ve bu paradoksların sonu yoktur. $\mathrm{Bu}$ nedenden dolayı, sûfiler eserlerinin uzman olmayanlarca yorumlanmasına sürekli olarak karşı durmuşlardır. Prof. Arkoun yalnızca tarihî metinlerde yazılanları okuma eğilimini eleştirir; ne var ki bu eğilimi, zaman zaman yanlış yorumlanmış sûfî metinlerine sıra geldiğinde daha da önemlidir. İslâma dâir kesinlikle büyük çekinceleri olan bir şarkiyatçı olan W. H. T. Gairdner'in Gazzâlı̂'nin Mişkâtü'l-Envâr'ına yaptığı tercümesine girişte, sûfi edebiyatına dâir şunları yazar-veya şu soruları sorar:"Onların dillerini çok ciddiye almalı miyız? Bu dil bilimselmiş gibi bir görüntü sergiler, ancak aslında şiirseldir." Bu sorunun kesinlikle doğru ortaya konulduğuna inanılabilir. Aksi takdirde, metinleri, kelimelerin ve kavramların yazıldıkları devirde ne anlama geldiklerine dâir bilgiye göre yorumlamaktan başka bir şey yapılamaz (Schimmel, 2014: 158-159).

Bir hükümdarın her zaman danışmanları olmalıdır. Hükümdar tavsiye istemekten çekinmemeli, sabırlı bir dinleyici olmalıdır. Kendisine doğruları söylemekten kaçınıldığını hissettiğinde de rahatsız olmalıdır. Bilge olarak nam salmış hükümdarların bunu kendi erdemlerine değil, etrafındaki akıllı danışmanlara borçlu olduğunu düşünen kimseler yanılıyorlardır. Zirâ akılsız hükümdarların, akıllı danışmanlara sahip olamayacağı evrensel ve şaşmaz bir kuraldır. İyi nasihatler nereden gelirse gelsin hükümdarın akıllı danışmanlarında değil ihtiyat ve zekâsında can bulurlar (Machiavelli, 2013: 156-157). Âlimler için en önemli görev, devlet başkanına yapılan nasihat ve halkın ihtiyaçlarını ona arz etmekten ibarettir. Gazzâlî, bu görevi çekinmeden ve her firsatta mektupları sayesinde yerine getirmiştir. Selçuklu vezir ve sultanlarına yazdığı mektuplarında, nasihatin önemi sadedinde Hz. Peygamberin biz Müslümanlara iki nasihatçi bıraktığını, bunlardan birinin Kur'an, diğerinin de ölüm gerçeği olduğunu belirtmiştir (Korkmaz, 1995: 78).

\subsubsection{Ilim Sahibi Olma}

XI. yüzyılda kitleleri kontrol etmenin en etkin aracı ulemâ idi ve bu yönüyle de idareciler ve zenginler tarafindan aranan bir güçtü. Nizâmiye medreselerinden önce, kitleleri dini ilimlerde uzmanlaşmış ulemâ aracılığıyla kontrol etmeyi sağlayan bir güç de yoktu (Çelikel, 2011: 138). Selçuklu döneminde bilginin müderrisler ve ulemâların otoritesi vasitasıyla aktarılması süreci iyice kurumsallaşmıştır (Ghazzal, 2011: 87). Gazzâlı̂’nin yaşadığı XI. yy Bağdat'ına dâir önemli çalışmaları olan Makdisî, Nizâmiye medreselerinin kuruluş amacını sorgularken, Nizâmülmülk'ün medreseleri, yönetimi altındaki geniş topraklarda kendi siyâsî icraatlarını gerçekleştirebilmek amaciyla kurduğunu söylemiştir.

İlim sahibi olmanın ilk göstergesi lisânı ustalıkla kullanabilmektir. Zira dilin etkisi diğer organların etkilerinden fazladır. Çünkü dil, kalbin tercümanıdır (Gazzâlî, 2004: 179). Bir iyiliği olsa bile, bunu hükümsüz kılacak miktarda kötülükleri olan kimseyi tezkiye etmemek, onu iyi bir insan veya Müslüman olduğunu söylememek dilin âfetlerindendir. Çünkü bir insanın iyi olması, iyiliklerinin kötülüklerinden fazla olmasıyla sabit olur (Gazzâlî, 2004: 199). Yöneticinin ilk şartı dilindedir. Onun dilinde öyle bir kudret olmalı ki her bildiğini iyi tahayyül edip güzel sözle ifade etsin, saadeti ve saadete ulaştırıcı işleri öğretsin ve bu meyanda cüz'iyatla ilgili olan işleri görebilmek için vücutça sağlam ve dayanıklı olsun.
Sonra kendisine söylenen her şeyi tabiatı ile iyi kavrayıp anlaması lazımdır ki hemen söyleyenin maksadını hem konu mevzû olan şeyi olduğu gibi anlasın (Fârâbî, 1956: 72). Gazzâlî’nin mektuplarında incitici sözleri neticesinde âkibetinin hüsran olduğu kişiler örnek verilerek Selçuklu emirlerine tavsiye bâbında satırlar yer almaktadır.

Hükümdarın ilim sahibi olmasının yanında ilim insanlarının da oynadığ1 rol mühimdir. "Organik aydın" tanımlamasıyla meşhur olan Gramsci'ye göre aydınları düşünce, bilgi ve bilim yayıcı kişiler olarak kabul etmek, bir efsaneden ibarettir. Onlar egemenlerin memurlarıdır ve hâkim zümreye organik bağlarla bağlıdırlar. Dolayısıyla aydınlar, hâkim sınıfa göre asla bağımsız değildir. Bu yargı, geleneksel büyük aydınlar için daha da geçerlidir. Her toplumsal zümre kendi özel aydınlar tabakasına sahiptir veya bu tabakayı yaratmaya çalışır. İktidardaki grup hem yı̆̆ınların desteğini kazanmak hem de onları ideolojik ve ahlâkî düzeyde kendi dünya görüşüne uygun olarak biçimlendirmek için aydınlardan yararlanır. Yönetici zümrenin, ortaya çıkan yeni güçleri artık özümleyemeyeceği ve yönetemeyeceği ortaya çıktığı zaman, aydınlar, sindirmesi ne kadar zor olursa olsun, her ideolojiyi çiğner ve homojen bir hale getirirler. Bu yönüyle aydınlar, her besini özümlenir yapma işlevine sahip “mide suyu”na benzemektedirler (Çelikel, 2011: 149).

\subsubsection{Tevâzu ve Hilm}

Övmek, övülen kimseyi kibir, riyâ ve kendini beğenme gibi durumlara sevk ederse, böyle bir kimseyi övmekten sakınmak ve onu şükretmeye davet etmek lâzımdır. Çünkü başarılar ve iyilikler ancak Allâhu Teâlâ'nın yardım ve desteği ile sağlanabilirler. Allâh Resûlü bu sebepten ölçüleri aşacak şekilde övmeyi yasaklamıştır (Gazzâlî, 2004: 199).

Kudret kendi gücüne dayanmakta değil, Allâhu Teâlâ'nın güç ve kudretinden yardım dilemekte ve O'na güvenmektedir. Çünkü insanın kudreti zorluklar karşısında iflas edip acze dönüşür. Allâhu Teâlâ'nın kudreti ise, bütün zorlukların üstündedir. Zorluklar O'nun kudreti karşısında kolaylaşıp uysallaşırlar. Bu sebeple, bu kuvvetten yardım alabilen bir kul gerçek anlamda güçlü ve kudreti olur (Gazzâlî, 2004: 232).

Bütün bu özelliklerin tek bir insanda bulunması zordur. Dolayısıyla insanlar arasında doğuştan bu özelliklere sahip sadece bir insan bulunabilir (Kaya, 2014: 146).

\section{Sonuç}

İslâm bilginleri içerisinde tartışmasız mühim bir yere sahip olan Gazzâlî, mektuplarında siyâseti, yalnız dar manada hakları paylaştıran, sosyal birliği koruyan, sorumlulukları düzenleyen cismani bir yönetim saymakla yetinmemiş, bunun yanında ve daha da önemlisi, İslâm'ın itikâdî ve ahlâkî boyutuna uygun olarak, toplumdaki herkesin manevî gelişmesini ve en yüksek mutluluktan pay almasını sağlayıcı bütün imkânları araştıran bir disiplin olarak görmüştür. $\mathrm{Bu}$, siyasetin bir peygamber mesleği olmasının gereğidir.

İktidara tavsiye boyutunda yazılmış mektuplar tarzındaki bu eserlerin odaklandığı esas mevzular, genel itibariyle, ideal yöneticilerin sahip olması gerektiğine inandıkları hasletler ve memleketlerinin bekâsı, tebaalarının saadeti için yapmaları lâzım gelenlerle ilgilidir. Gözden kaçırılmaması gereken nokta müelliflerinin konulara, siyaset üzerine çalışmalar yapan hem fakihlerden hem de filozoflardan farklı bir yaklaşım sergilemeleridir. Dönemin yöneticilerine öğütleri hâvî bu 
eserler, deneyime dayalı devlet idaresi ve yöneticilerin görevlerinin belirlenmesi ve tanımlanmasını amaçlayarak idareci sınıfların pratik ahlâkını yansıtır. Gazzâlî hükümdarlar için ahlâk ve yönetim anlayışı çizmiş, hükümdarın davranış ve hâkimiyetinin pratik sonuçlarını ele alan ideal bir toplum ve yönetim anlayışını benimsemiştir.

Sünnî siyaset ile siyasî gücün ana akımını ve onun dinî-hukukî sınırlarını belirleyen isimlerden birisi olan Gazzâlî'nin mektupları İslâm dünyasındaki siyasal durumun Büyük Selçukluların tarih sahnesine çıkması ile kökten bir değişim geçirdiği ve bu değişimin siyaset teorisine değinen çalışmalara da yansıdığı bir dönemde kalemde alınmıştır. Eserinde idare kurumunu temellendirme veya sistematik bir açıklamasını yaparak felsefi bir gerekçelendirmeye gitmek yerine hükümdarın davranışlarıyla ve hükümdarlığının pratik sonuçlarıyla ilgilenmiştir. Buna mukâbil, sultan zorba olursa da dünya harap bir yer olacaktır. Adaletin nasıl tesis edileceğine dair verdiği öğütleri, sultanın şahsında olması gereken özellikler ve sultanın hükmederken dikkat etmesi gereken hususları belirtmiştir. Gazzâlî, devlet başkanına siyaset anlayışında önemli bir yer vermektedir. Sonuç itibariyle O’na göre kötü bir devlet başkanı bile devlet başkanının olmamasından daha iyidir.

\section{Kaynakça}

Abdü'l-Kayyûm. (2002). İmam Gazzâlî’nin Mektuplart. (Orj.ad1 Letters of Al-Ghazzali, Lahor, 1982), (terc. Gürsel Uğurlu). İstanbul: İnkılâb Yayınları.

\section{Bhavan. India.}

(1992). Letters of Al-Ghazzali. Kitab

Annemarie, S. (2014). Tasavvufta Ak1l ve Mistik Tecrübe. İslâm'da Entelektüel Gelenekler. (Farhad Daftary). İstanbul: İnsan Yayınları.

Çelikel, B. (2011). Ulemânın İhaneti: Gazzâlî’nin Ulemâ Eleştirisi. T.B.Y. Akademi. Ocak. 137-153.

Çubukçu, İ. A. (1964). Gazzâlî ve Şüphecilik. Ankara: Üniversite Basımevi.

Fârâbî, (1956). El-Medinetü'l-Fâzıla. (terc. Nâfiz Danışman). İstanbul: Maarif Basımevi.

Gazzâlî, (2004). Dinde Kırk Prensip, Kitabu'l-Erbain fî-Usûli ve'd-Dîn. (tehzip ve tekmil Abdulhalık Duran). İstanbul:
Kayıhan Yayınları.

(1969). Nasihatü'l-Mülûk (Devlet Başkanlarına Nasihatler). (terc. Osman Şekerci). İstanbul: Sinan Yayınları. (1962). el-İktisat fi'l-İ'tikâd. (haz. İ. Agâh ÇubukçuHüseyin Atay). Ankara: A. Ü.İlahiyat Fakültesi Yayınları.

--------, (1994). el-Mustasfa min İlmi'l-Usul, İslâm Hukukunda Deliller ve Yorum Metodolojisi. c. I. (terc. Yunus Apaydın). Kayseri: Rey Yayınları.

Ghazzal, Z. (2011). Ulemâ: Statüsü ve İşlevi. Ortadoğu Tarihi. (haz. Youssef M. Choueiri). İstanbul: İnkılâp Yayınları.

Güngör, E. (2003). Sosyal Meseleler ve Aydınlar. (Haz. R. Güler, E. Kılınç). İstanbul: Ötüken Neşr.

Hitti, P. K. (2011). Siyâsî ve Kültürel İslâm Tarihi. (çev. Salih Tuğ). İstanbul: İ.F.A.V. Yayınları.

Humphreys, S. R. (2004). İslâm Tarih Metodolojisi. (çev. Murtaza Bedir-Fuat Aydın). İstanbul: Litera Yayınları.

Machiavelli, N. (2013). Hükümdar. (çev. Sena Öksüz). İstanbul: Martı Yayınları.

Mâverdî, (1978). Edebü'd-Dünya ve'd-Din. Beyrut: Dâru'lİhyâ-i Ulûm.

Mâverdî, (1985). el-Ahkâmü's-Sultâniyye ve'l-Vilâyetü'dDiniyye. Beyrut: Dâru'l-Kütübi'l-İlmiyye.

Şeşen, R. (1990). İslâm Medeniyeti Tarihi. İstanbul: İSAR Vakfi Yayınları.

Kaya, M. (2014). İslâm Filozoflarından Felsefe Metinleri. İstanbul: Klasik Yayınları.

Korkmaz, F. (1995). Gazzâlî’de Devlet. Ankara: T.D.V.Yayınları.

Köymen, M. A. (2011). Alp Arslan ve Zamanı. Ankara: T.T.K. Yayınları.

Lewis, B. (2011). İslâm’ın Siyasal Söylemi. (çev. Ünsal Oskay). Ankara: Phoneix Yayınları.

Taylan, N. (1994). Düşünce Sisteminin Temelleri. İstanbul: İFAV Yayınları.

Yazar, N. (2016). Gazzâlî’nin Nasihatü'l-Müluk Adlı Eserinde Hükümdarlık Teorisi, 1. Türk İslâm Siyâŝ̂ Düşüncesi Kongresi Bildiriler Kitabı. 8-10 Ekim, Aksaray. 149-161. 